\title{
Canadian consensus guidelines for the management of cytomegalovirus disease in HIV/AIDS
}

\author{
Richard G Lalonde MD FRCPC ${ }^{1}$, Guy Boivin MD MSc FRCPC ${ }^{2}$, Jean Deschênes MD FRCSC ${ }^{3}$, \\ William G Hodge MD PhD FRCSC ${ }^{4}$, J jill Hopkins MD FRCSC ${ }^{5}$, Alex H Klein MD ${ }^{6}$, Janette I Lindley MD FRCSC ${ }^{7}$, \\ Peter Phillips $M D^{8}$, Stephen D Shafran $M D^{9}$, Sharon Walmsley $M^{10}$ \\ Reviewed by the AMMI Guidelines Committee: \\ G Evans, Chair; M Laverdiere; L Nicolle; P Phillips; C Quan; and C Rotstein
}

RG Lalonde, G Boivin, J Deschênes, et al. Canadian consensus
guidelines for the management of cytomegalovirus disease in
HIV/AIDS. Can J Infect Dis Med Microbiol 2004;15(6):327-335.

BACKGROUND: The management of HIV-infected patients with cytomegalovirus (CMV) disease has changed significantly with the availability of highly active antiretroviral therapy (HAART).

OBJECTIVES: These updated guidelines are intended to provide practical help to physicians managing HIV-positive patients with or at risk for CMV disease.

METHODS: The 10 members of the Canadian CMV Disease in HIV/AIDS Consensus Group were infectious disease specialists, a primary care physician and ophthalmologists with expertise in HIV and CMV infection. Financial support by Hoffmann-La Roche Canada Ltd was unrestricted, and was limited to travel expenses and honoraria. The consensus group met in June and October 2002. Key areas to be considered were identified, and group members selected, reviewed and presented relevant recent literature for their assigned section for the group's consideration. Evidence was assessed based on established criteria, which were expert opinions of the members. Draft documents were circulated to the entire group and modified until consensus was reached. The final guidelines represent the group's consensus agreement. The guidelines were approved by the Canadian Infectious Disease Society.

RESULTS AND CONCLUSIONS: The guidelines address symptom monitoring, screening for early detection and prevention, and treatment using oral, intravenous and intraocular anti-CMV therapies in conjunction with HAART.

Key Words: Cytomegalovirus disease; Diagnosis; Guidelines; HIVIAIDS; Screening; Treatment

\section{Directives consensuelles canadiennes sur le traitement de l'infection à $\mathrm{CMV}$ en présence de $\mathrm{VIH} /$ sida}

HISTORIQUE : Le traitement des patients VIH-positifs infectés par le cytomégalovirus (CMV) a significativement changé depuis l'avènement des schémas antirétroviraux hautement actifs ou HAART (pour highly active antiretroviral therapy).

OBJECTIF : Avec cette mise à jour des directives, le groupe d'expert espère venir en aide aux médecins qui soignent des patients VIH-positifs souffrant ou risquant de souffrir de maladie à CMV.

MÉTHODES : Au nombre de dix, les membres du groupe d'experts canadiens sur la maladie à CMV dans le contexte du VIH/sida comprenaient des infectiologues, un médecin de premier recours et des ophtalmologistes, tous spécialistes de l'infection au VIH et au CMV. Le soutien financier de Hoffmann-La Roche Canada ltée a été offert sans restriction et a couvert exclusivement les frais de déplacements et les honoraires des experts. Le groupe s'est rencontré en juin, puis en octobre 2002. Les domaines jugés importants ont été identifiés et les membres ont sélectionné, analysé et présenté au groupe les articles scientifiques récents pertinents sur les thèmes qui leur avaient été assignés. La qualité des preuves a été évaluée en fonction de critères établis et tenait compte de l'opinion experte des membres. Des ébauches ont circulé au sein de tout le groupe et ont été modifiées jusqu'à l'atteinte d'un consensus, reflété dans les directives finales. Ces directives ont reçu l'aval de la Société canadienne des maladies infectieuses.

RÉSULTATS ET CONCLUSION : Les directives portent sur la surveillance des symptômes, le dépistage de la maladie, sa prévention précoce et son traitement à l'aide d'agents anti-CMV oraux, intraveineux et intra-oculaires, alliés à une HAART.

${ }^{1}$ Division of Infectious Diseases, McGill University Health Centre, Montréal, Quebec; ${ }^{2}$ Department of Medical Biology, Centre Hospitalier Universitaire de Québec-Centre Hospitalier de l'Université Laval and Université Laval, Sainte-Foy, Quebec; ${ }^{3}$ Department of Ophthalmology, McGill University Health Centre, Montréal, Quebec; ${ }^{4}$ University of Ottawa Eye Institute, Ottawa, Ontario; ${ }^{5}$ Department of Ophthalmology, University of Toronto, Sunnybrook and Women's College Health Sciences Centre, Toronto, Ontario; ${ }^{6}$ Department of Family Medicine, Mount Sinai Hospital, Toronto, Ontario; ${ }^{7}$ Department of Ophthalmology and Visual Sciences; ${ }^{8}$ Division of Infectious Diseases, St Paul's Hospital, University of British Columbia, Vancouver, British Columbia; ${ }^{9}$ Division of Infectious Diseases, Department of Medicine, University of Alberta, Edmonton, Alberta; ${ }^{10}$ Department of Medicine, Division of Infectious Diseases, University of Toronto, Toronto General Hospital, Toronto, Ontario

Correspondence and reprints: Dr Richard Lalonde, Montreal Chest Institute, McGill University Health Centre, 3650 Saint Urbain Street,

Montreal, Quebec H2X 2P4. Telephone 514-843-2090, fax 514-843-2092, e-mail richard.lalonde@muhc.mcgill.ca

Received and accepted for publication June 1, 2004. 
C yytomegalovirus (CMV) infection is lifelong, typically acquired in childhood or adolescence, and usually asymptomatic. When T lymphocyte dysfunction occurs, CMV can reactivate and lead to disease $(1,2)$. Before the advent of highly active antiretroviral therapy (HAART) for HIV infection, the most common CMV disease site was the retina, followed by the gastrointestinal (GI) tract and, less frequently, the central nervous system and respiratory tract (3).

Two major risk factors for CMV disease are CMV seropositivity and a low CD4 cell count $(3,4)$. Other factors also play a role (Table 1). Before HAART, most patients had CD4 counts less than 100 cells $/ \mu \mathrm{L}$, and $75 \%$ to $80 \%$ of cases occurred in

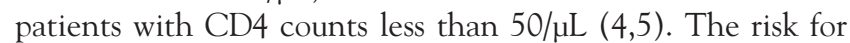
CMV retinitis in patients with a CD4 count less than 100 cells $/ \mu L$ was $25 \%$ over four years (4). In the post-HAART era, CMV disease can occur in patients with higher CD4 counts within the first two months of HAART if they have a pretreatment CD4 count less than 100 cells/ $\mu \mathrm{L}$ (6). The incidence of CMV retinitis in HIV-positive patients has declined by $55 \%$ to $80 \%$ since HAART was introduced $(7,8)$.

Pre-HAART progression of CMV retinitis, if left untreated, destroyed the retina and led to blindness within six months $(7,9)$. Even with treatment, the outcome of CMV retinitis was poor because of frequent relapses, sometimes complicated by retinal detachment (10). Today, some clinical manifestations of CMV disease have changed (7), but outcomes are far better because patients receive both anti-CMV therapy and HAART $(11,12)$, and the resulting immune reconstitution helps to keep the CMV infection quiescent (6).

Updated guidelines for the management of CMV disease in patients with HIV infection are needed for three reasons. First, clinical expertise with CMV disease has decreased due to decreased incidence and relapse rates. Second, immune reconstitution due to HAART has modified the disease characteristics associated with CMV. Finally, the recent approval of an oral anti-CMV drug may result in increased involvement by community-based primary care physicians in the management of CMV disease.

To provide current guidance on the management of CMV disease in patients with HIV infection, a 10-member Canadian CMV Disease in HIV/AIDS Consensus Group was formed by inviting all infectious disease specialists and ophthalmologists in Canada with a significant HIV-related practice. The group consisted of those specialists who chose to participate and a primary care physician with expertise in CMV and HIV infection. Meetings were held in June and October 2002. Areas to be discussed were identified, and group members reviewed and presented relevant recent literature for their assigned section to the group for discussion. The quality of the evidence used in the guidelines was graded according to a system developed by the Infectious Disease Society of America (Table 2) (13). Expert opinions of the group members were included as evidence. Draft documents were circulated to the entire group and modified until a consensus was reached. The final guidelines represent the group's consensus agreement. The guidelines were approved by the Canadian Infectious Disease Society.

The recommendations contained in these guidelines are intended for use by health care providers who treat adults with HIV infection. These recommendations are not a substitute for the judgment of a physician experienced in treating HIV-related CMV disease.

\section{TABLE 1}

Risk factors for cytomegalovirus (CMV) disease

\begin{tabular}{|c|c|}
\hline Risk factors for CMV disease & References \\
\hline CMV seropositivity & Shepp et al (3) \\
\hline CD4 cell count nadir $<100$ cells $/ \mu \mathrm{L}$ & Gallant et al (2) \\
\hline $\begin{array}{l}\text { Prior occurrence of other } \\
\text { opportunistic infections }\end{array}$ & Burke et al (54) \\
\hline $\begin{array}{l}\mathrm{CMV} \text { viremia in polymorphonuclear } \\
\text { leukocytes or plasma }\end{array}$ & $\begin{array}{l}\text { Dodt et al (28), } \\
\text { Casado et al (55), } \\
\text { Spector et al (29), } \\
\text { Walmsley et al (30) }\end{array}$ \\
\hline HIV plasma viremia & Spector et al (29) \\
\hline $\begin{array}{l}\text { Prior retinal damage } \\
\text { (cotton wool spots) }\end{array}$ & Jacobson and Mills (56) \\
\hline $\begin{array}{l}\text { Previous CMV disease } \\
\text { (retinal or extraocular) }\end{array}$ & Verbraak et al (31) \\
\hline Lack of anti-CMV therapy & Spector et al (57) \\
\hline $\begin{array}{l}\text { Lack of highly active antiretroviral } \\
\text { therapy (HAART) }\end{array}$ & Verbraak et al (14) \\
\hline
\end{tabular}

TABLE 2

Categories reflecting the strength of each

recommendation for or against use

\begin{tabular}{ll}
\hline Category & Definition \\
\hline A & Good evidence in support of a recommendation for use \\
B & Moderate evidence to support a recommendation for use \\
C & Poor evidence to support a recommendation for or against use \\
D & Moderate evidence to support a recommendation against use \\
E & Good evidence to support a recommendation against use
\end{tabular}

Categories reflecting the quality of evidence on which recommendations are based

\begin{tabular}{ll}
\hline Grade & Definition \\
\hline I & Evidence from at least one properly randomized, controlled trial \\
II & Evidence from at least one well-designed clinical trial without \\
& randomization from cohort or case-controlled analytic studies \\
& (preferably from more than one centre), from multiple time-series \\
& studies, or from dramatic results in uncontrolled experiments \\
III $\quad$ Evidence from opinions of respected authorities, based on clinical \\
\end{tabular}

Reprinted from reference 13 with permission

\section{DIAGNOSIS}

Risk factors for CMV disease in HIV-infected patients should be taken into account in the diagnosis (Table 3). Patients who are not taking HAART and who have a CD4 count less than 100 cells $/ \mu \mathrm{L}$ are at highest risk (evidence grade IIB) (14), while those with a CD 4 count less than 100 cells/ $\mu L$ despite HAART (evidence grade IIB) (12) or who fail HAART (evidence grade IIIB) (12) are at moderate risk. Also at risk are those patients with a pre-HAART CD4 count nadir less than 100 cells/ $\mu \mathrm{L}$ and any increase in CD4 count in response to HAART within two months of its initiation (evidence grade IIB) (6). 
TABLE 3

Risk factors for cytomegalovirus (CMV) disease in HIV-infected patients in the highly active antiretroviral therapy (HAART) era

- Patients not taking HAART with CD4 $<100$ cells/ $\mu \mathrm{L}$ (evidence grade IIB) (14)*

- Patients with CD4 <100 cells/ $\mu \mathrm{L}$ despite HAART (evidence grade IIIB) (12)

- Patients with CD4 <100 cells/ $\mu \mathrm{L}$ who fail HAART (evidence grade IIB) (12)

- Patients with CD4 $<100$ cells/ $\mu \mathrm{L}$ before HAART initiation and an immune response to HAART (any increase in CD4 count) within the first two months of its initiation (evidence grade IIB) $(6)^{\dagger}$

- Patients with a good virological response to HAART but persistent CD4 lymphopenia. These patients have lower risk of opportunistic infections compared with untreated patients with similar CD4 counts (evidence grade IIB) (11)

* Rare cases of CMV retinitis have been diagnosed in patients with $C D 4$ counts above 100 cells/ $\mu \mathrm{L}$, mainly in those who have recently started HAART (11). Thus, physicians should keep in mind that patients who have ocular symptoms and a CD4 count greater than 100 cells/ $\mu L$ may develop CMV retinitis. ${ }^{\dagger}$ These patients are at increased risk of developing either CMV retinitis or immune recovery uveitis

\section{CMV retinitis}

Patients may present with a loss of vision, blurred/cloudy vision, light flashes, floaters (spots that appear to drift in front of the eye) or scotomata (blind spots) $(10,15)$. However, CMV retinitis can be asymptomatic (16). CMV retinitis is diagnosed by an eye care professional through examination of the dilated retina, including the periphery $(10,17)$. Examination of the retina reveals necrosis, a hemorrhagic yellow-white infiltrate that follows the vascular pattern with little vitreous inflammation $(10,17,18)$ (Figures $1 \mathrm{~A}$ and $1 \mathrm{~B}$ ). In patients on HAART, CMV retinitis may be more subtle, with a more focal greyish and granular appearance and little or no hemorrhage (Figure 1C).

HIV-positive patients should be educated about the symptoms and consequences of CMV retinitis, and encouraged to report visual symptoms early.

\section{Recommendations}

- Prompt dilated ocular examination by an eye care professional is required for patients at risk for CMV retinitis who have visual symptoms (evidence grade IIA). If active retinitis is present, photographs or drawings should be used to monitor disease progression (evidence grade IIB) $(10,19)$

\section{Immune recovery uveitis}

Immune recovery uveitis (IRU) has emerged as a new clinical entity in patients treated successfully with HAART who previously had CMV retinitis. IRU is an intraocular inflammation in response to CMV antigens, not a reactivation of CMV retinitis (20). The incidence of IRU varies from 0.11 /year to 0.83 year $(21,22)$ and occurs weeks to months following HAART initiation (22). Patients may note blurred vision, floaters, a loss of visual acuity (22) or, sometimes, ocular pain. Eye examinations may show cystoid macular edema, epiretinal membrane, proliferative vitreoretinopathy, spontaneous vitreal hemorrhage, posterior subcapsular cataracts or persistent anterior chamber inflammation (23). Treatment with topical steroids alone often suffices.
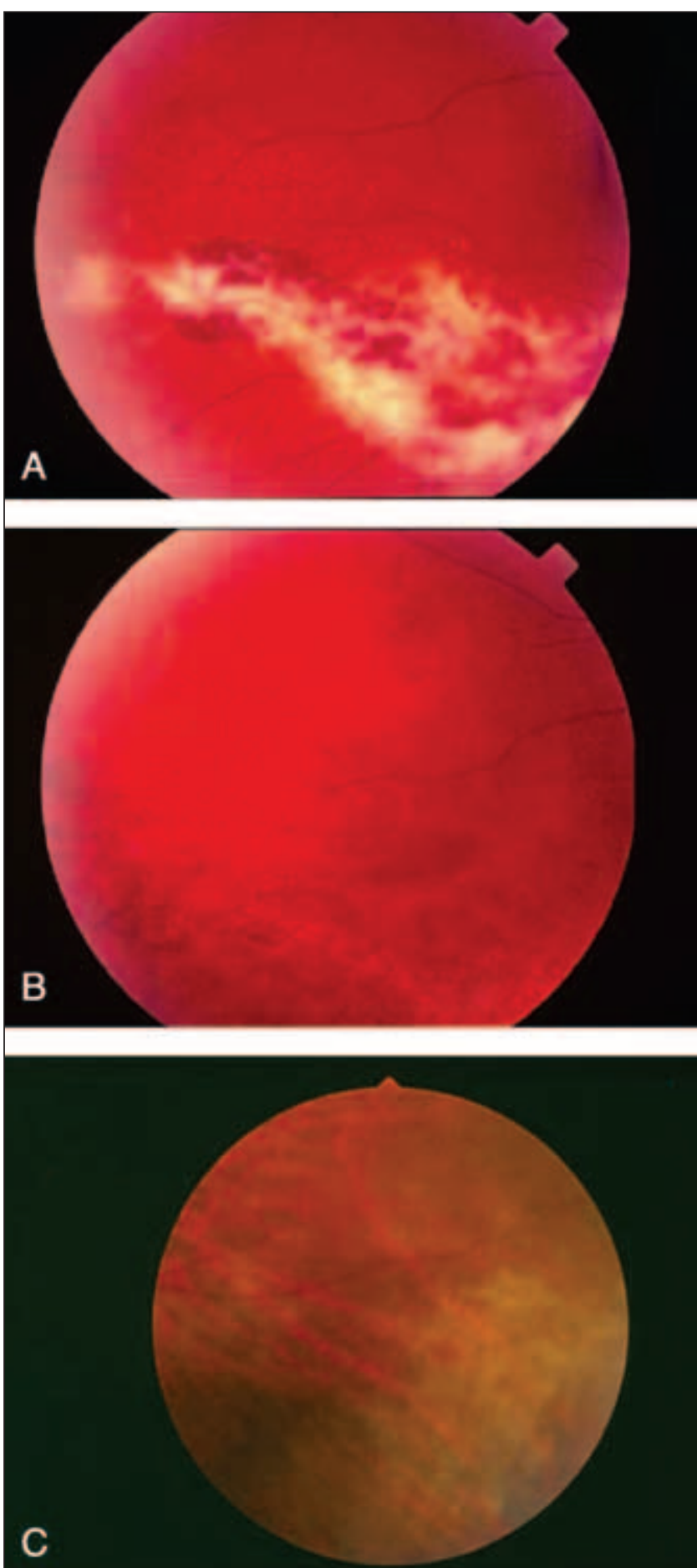

Figure 1) Appearance of cytomegalovirus (CMV) retinitis pre- and post-highly active antiretroviral therapy (HAART). A Retina of patient with CMV retinitis pre-HAART and before anti-CMV treatment; B Retina of the same patient pre-HAART and after anti-CMV treatment; $\mathrm{C}$ Retinal periphery of another patient post-HAART and before anti-CMV treatment with an inferonasal patch of greyish, indistinct CMV retinitis in lower right surrounded by normal retina

Nonocular CMV Disease

The diagnosis of nonocular CMV disease is difficult because clinical manifestations are not specific and there are no simple 
TABLE 4

Clinical and laboratory manifestations of nonocular cytomegalovirus (CMV) disease*

\begin{tabular}{|c|c|c|}
\hline Affected area & Disease & $\begin{array}{l}\text { Clinical and laboratory } \\
\text { manifestations/indicators }\end{array}$ \\
\hline \multirow[t]{2}{*}{ Gastrointestinal tract } & Colitis & $\begin{array}{l}\text { - Abdominal pain } \\
\text { - Fever } \\
\text { - Weight loss } \\
\text { - Diarrhea } \\
\text { - Gastrointestinal bleeding } \\
\text { - Concomitant CMV retinitis }\end{array}$ \\
\hline & Esophagitis & $\begin{array}{l}\text { - Odynophagia } \\
\text { - Retrosternal pain } \\
\text { - Dysphagia } \\
\text { - Weight loss } \\
\text { - Classic endoscopic picture of } \\
\text { shallow ulcers, usually in the } \\
\text { distal one-third of the esophagus } \\
\text { - Concomitant CMV retinitis }\end{array}$ \\
\hline \multirow[t]{3}{*}{$\begin{array}{l}\text { Central nervous } \\
\text { system }\end{array}$} & Polyradiculitis & $\begin{array}{l}\text { - Guillain-Barre-like presentation } \\
\text { (except for anal sphincter } \\
\text { involvement and sparing of } \\
\text { upper extremities) } \\
\text { - Ascending lower motor neuron } \\
\text { weakness of legs } \\
\text { - Loss of sphincter function } \\
\text { - Cerebrospinal fluid: Increased } \\
\text { polymorphonuclear leukocytes, } \\
\text { increased protein, a slight } \\
\text { decrease in glucose; positive for } \\
\text { CMV-DNA using polymerase } \\
\text { chain reaction }\end{array}$ \\
\hline & Encephalitis & $\begin{array}{l}\text { - Confusion } \\
\text { - Decreased level of consciousness } \\
\text { - Cognitive impairment } \\
\text { - Headache } \\
\text { - Seizures } \\
\text { - Fever } \\
\text { - Periventricular enhancement } \\
\text { on infused computed } \\
\text { tomography scan }\end{array}$ \\
\hline & Neuropathy & $\begin{array}{l}\text { - Numbness or burning of the skin } \\
\text { - Allodynia, especially in feet and } \\
\text { lower extremities } \\
\text { - Decreased reflexes, weakness }\end{array}$ \\
\hline Respiratory tract & Pneumonia & $\begin{array}{l}\text { - Cough } \\
\text { - Dyspnea } \\
\text { - Fever } \\
\text { - Interstitial infiltrates on x-ray }\end{array}$ \\
\hline
\end{tabular}

${ }^{*}$ CMV infection can also rarely cause adrenal insufficiency and sclerosing cholangitis (HIV cholangiopathy). CMV may also cause a nonspecific febrile syndrome, with markers of active CMV replication in the blood and usually mild to moderately low neutrophil and platelet counts

blood tests. Diagnosis is confirmed when typical intracellular CMV inclusions are seen or CMV antigens are demonstrated in a biopsy of the involved organ. Table 4 highlights the clinical presentation and laboratory indicators of several nonocular sites of CMV disease.

\section{Recommendations}

- Before initiating anti-CMV treatment, the diagnosis of CMV disease should be confirmed through detection of CMV inclusions or antigen on organ biopsy (evidence grade IIB) (24-26). Positive cultures or molecular tests from organ tissue alone are not sufficiently specific (evidence grade IID) (26).

- A positive test for CMV DNA in cerebrospinal fluid confirms neurological CMV disease (evidence grade IIA).

- When tissue biopsy is not feasible, tests for CMV replication in the blood, although less specific, should be used to improve the level of diagnostic certainty (evidence grade IIIB). However, the types and threshold values of assays are still debated.

\section{SCREENING FOR CMV DISEASE}

Laboratory screening

CMV seropositivity is highly prevalent in HIV-infected patients $(80 \%$ to $95 \%)(3,4)$. Seropositivity does not distinguish between latent and active CMV disease. However, CMV seronegativity does rule out CMV disease (3).

CMV disease is usually preceded by CMV replication in blood, urine or saliva. In transplant recipients, the use of antiCMV drugs when CMV reactivation is detected prevents the occurrence of end organ disease, a strategy called pre-emptive therapy (1). In asymptomatic HIV-infected patients, CMV reactivation identifies an increased risk for CMV disease (27-30), but the value of pre-emptive therapy in this patient population has not been established.

\section{Recommendations}

- Specific recommendations about use and frequency of tests for CMV replication for pre-emptive therapy cannot be made because of the absence of randomized, controlled clinical studies to support their use (evidence grade IIC).

- Blood CMV serology testing should be considered for HIV-positive, previously CMV-seronegative patients who may receive blood products (evidence grade IIIC), because CMV-negative or leukocyte-deficient blood products should be considered.

Ocular examinations and screening for CMV retinitis CMV retinitis can be detected before it becomes symptomatic (16). While the consensus group felt that early detection may be beneficial, especially for high-risk patients (Table 3), there are no data to support a recommendation for routine ophthalmology screening examinations or for the appropriate interval between examinations in asymptomatic patients (evidence grade IIIC) $(12,27)$.

\section{Recommendations}

- Due to increased risk of CMV retinitis, patients with extraocular CMV disease should receive an eye examination (evidence grade IIA) $(10,31)$. 


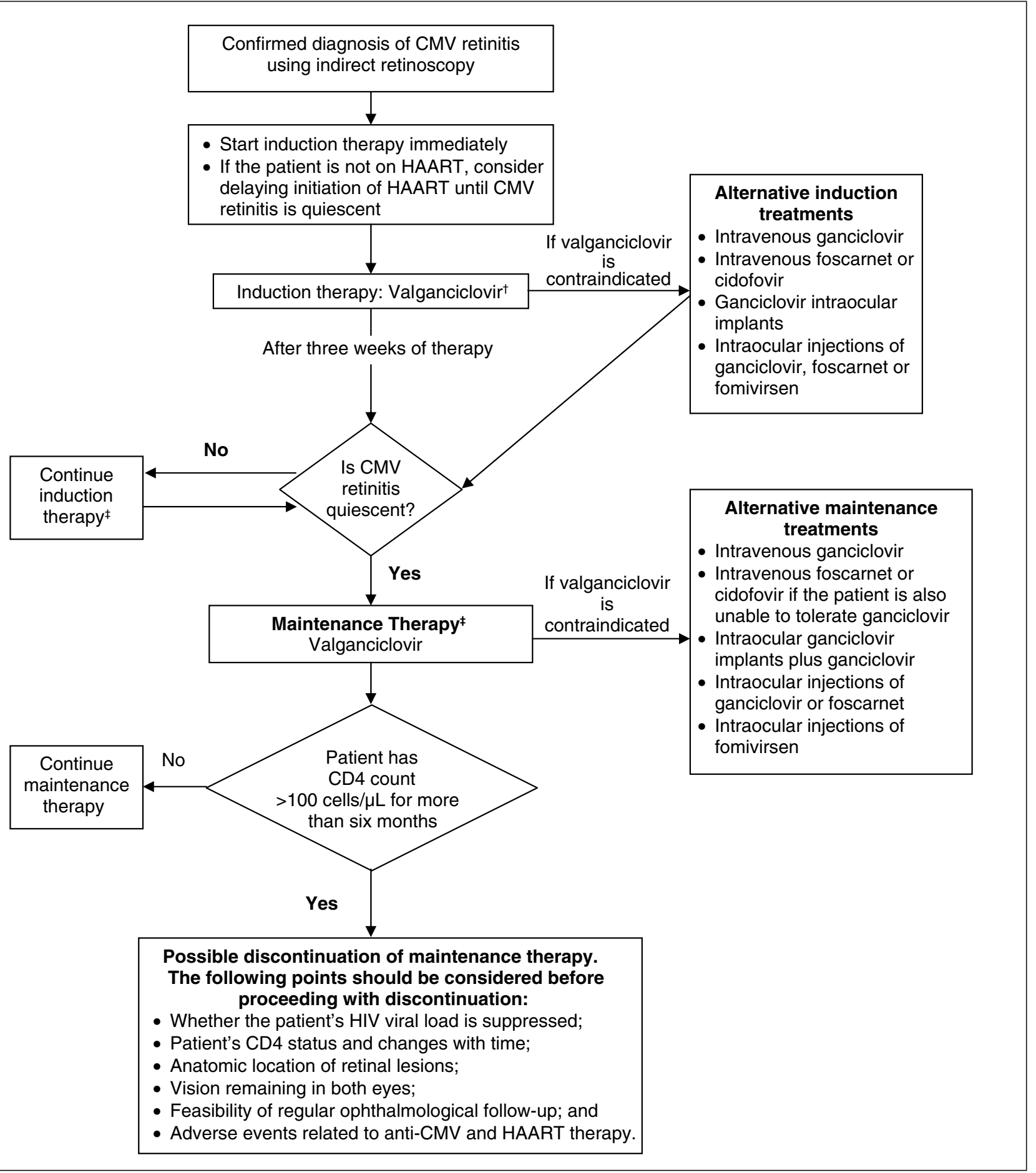

Figure 2) Algorithm for the management of cytomegalovirus (CMV) retinitis in HIV/AIDS. * See text for discussion of the treatment of nonocular $\mathrm{CMV}$ disease. ${ }^{\dagger}$ Also consider intraocular therapy in cases where the patient's vision is in immediate danger. FSee text for information about relapses and refractory disease. HAART Highly active antiretroviral therapy

\section{TREATMENT OF CMV DISEASE}

Anti-CMV drugs are virustatic, not virucidal. Therefore, the goal of CMV disease treatment is control of the disease. Treatment begins with higher induction doses and, for CMV retinitis, induction is followed by lower dose maintenance therapy. Systemic (oral, intravenous [IV]) and local (intraocular injections and implants) anti-CMV therapies are available. For CMV retinitis, therapeutic drug concentrations are achieved much more quickly with intraocular therapy than with systemic therapy, but systemic therapy prevents occurrence in the other eye and other organs $(32,33)$.

CMV retinitis induction therapy

Until the advent of valganciclovir, CMV retinitis could only be treated by injectable or implantable drugs, requiring either an indwelling venous catheter, weekly intraocular injections, 


\section{TABLE 5}

Recommended induction and maintenance therapies for the treatment of cytomegalovirus (CMV) retinitis

\begin{tabular}{|c|c|c|c|}
\hline Therapy & Medication & Dose $^{*}$ & Evidence level \\
\hline \multicolumn{4}{|l|}{ Induction therapy ${ }^{\dagger}$} \\
\hline Recommended therapy & Valganciclovir (32) & $900 \mathrm{mg}$ by mouth twice a day & IA \\
\hline \multirow{7}{*}{ Alternative therapies } & IV foscarnet or IV cidofovir $(38,39)$ & IV foscarnet, $60 \mathrm{mg} / \mathrm{kg}$ every $8 \mathrm{~h}$ or & \\
\hline & & $90 \mathrm{mg} / \mathrm{kg}$ to $100 \mathrm{mg} / \mathrm{kg}$ every $12 \mathrm{~h}$ & IA \\
\hline & & $\begin{array}{l}\text { Cidofovir } 5 \mathrm{mg} / \mathrm{kg} \text { IV weekly for two weeks, } \\
\text { then every two weeks (maintenance) }\end{array}$ & \\
\hline & Intraocular injections & & \\
\hline & - Ganciclovir (58) & $0.4 \mathrm{mg}$ twice weekly & IIB \\
\hline & - Foscarnet (41) & $2.4 \mathrm{mg}$ every three days & IIB \\
\hline & - Fomivirsen (42) & $165 \mu \mathrm{g}$ every week for three weeks & IA \\
\hline \multicolumn{4}{|l|}{ Maintenance therapy $\ddagger$} \\
\hline \multirow{4}{*}{ Alternative therapies } & Ganciclovir intraocular implant (40) & Implant (release rate $1 \mu \mathrm{g} / \mathrm{hr}$ to $2 \mu \mathrm{g} / \mathrm{hr}$ ) every six to nine months & IA \\
\hline & Ganciclovir intraocular $(36,59)$ & Ganciclovir ( $0.4 \mathrm{mg}$ to $2 \mathrm{mg}$ once weekly) & IIB \\
\hline & or foscarnet intraocular (41) & Foscarnet (2.4 mg once weekly) & \\
\hline & Fomivirsen intraocular (42) & $165 \mu \mathrm{g}$ intraocular every two weeks & IA \\
\hline
\end{tabular}

*The doses of systemic medication listed are for patients with normal renal function. Patients with renal impairment may require dose reduction, as per the product monograph. ${ }^{\dagger}$ Recommended duration of induction treatment is a minimum of three weeks and should be continued until the CMV retinitis is quiescent. $¥$ For information regarding the duration of maintenance therapy, see the discussion in 'Discontinuation of CMV retinitis maintenance therapy' located in the text. IV Intravenous

or repeated use of drug-releasing implants into the vitreous cavity of the eye (32,34-36). Figure 2 is a treatment algorithm for the management of CMV retinitis.

\section{Recommendations}

- When the diagnosis of CMV retinitis is confirmed, therapy should be initiated immediately to prevent further retinal damage (evidence grade IA).

- If intraocular therapy is used, concomitant systemic therapy should still be considered to protect the other eye and other organs (evidence grade IIA) $(11,32,33)$.

- Local intraocular therapy alone may be used when systemic therapy is contraindicated. It also may be considered for adjunctive treatment in severe or relapsed cases where the patient's vision is in immediate danger (evidence grade IIIB).

- The recommended minimum duration of induction therapy is three weeks, followed by maintenance therapy once the CMV retinitis is quiescent (evidence grade IIA).

- Patients require weekly ophthalmological examinations until CMV retinitis is quiescent (evidence grade IIIA) (11).

- Oral valganciclovir is the induction therapy of choice based on its effectiveness, convenience, and the elimination of catheter-related complications of IV therapy (evidence grade IA) (Table 5) $(32,37)$.
- If valganciclovir is contraindicated, alternatives include: IV ganciclovir (evidence grade IA) (38); IV foscarnet (38) or cidofovir (evidence grade IA) (39); and finally, intraocular ganciclovir implants (evidence grade IA) $(33,40)$ or injections of ganciclovir (evidence grade IIB) (36), foscarnet (evidence grade IIB) (41) or fomivirsen (evidence grade IA) (Table 5) (42).

- Because immune recovery with HAART initiation may increase the severity of CMV or other opportunistic infections (eg, tuberculosis), it may be preferable to treat CMV disease first and, once it is quiescent, begin HAART (evidence grade IIIC).

- Levels of blood CMV viral load can be used to monitor the response to anti-CMV therapy $(43,44)$ and indicate the emergence of CMV drug resistance (evidence grade IIB) $(44,45)$.

CMV retinitis maintenance therapy (secondary prophylaxis) Maintenance therapy to delay progression is required in the treatment of CMV retinitis $(32,36,46,47)$.

\section{Recommendations}

- Before lowering the anti-CMV therapy dose to maintenance levels, remission must be confirmed by an ophthalmological examination.

- Frequent eye examinations are recommended to monitor the disease and detect relapse and development of IRU (evidence grade IIB) $(11,21)$. The frequency of 
ophthalmological follow-up must be individualized, taking into consideration the anatomical location of lesions, functional vision, CD4 count and HIV viral load (evidence grade IIIC).

- Patients not taking or ineffectively treated with antiretroviral therapy with CD4 counts of less than 200 cells $/ \mu \mathrm{L}$ should be monitored more carefully (evidence grade IIIC).

- Once daily valganciclovir is the maintenance therapy of choice because it is effective $(32,46)$ and it eliminates the dangers and inconvenience of IV administration (evidence grade IA) $(32,34,35,37,46)$ (Table 5).

- If valganciclovir is contraindicated, alternative maintenance therapies include: IV ganciclovir (evidence grade IA) (38); IV foscarnet (38) or cidofovir (evidence grade IA) (39); ganciclovir intraocular implants (evidence grade IA) $(33,40,48)$; intraocular injections of ganciclovir (36) or foscarnet (evidence grade IIB) (41); or finally, intraocular injections of fomivirsen (evidence grade IA) (42).

\section{CMV retinitis progression}

CMV retinitis progression may occur while patients are on therapy. Failure of anti-CMV therapy is probably due to inadequate ocular penetration of the medication, but may also indicate development of resistance to anti-CMV therapy. The physician must determine whether this progression is due to relapse or refractory disease. Refractory disease has been defined as two relapses within a 10 -week period despite two induction and maintenance cycles (10).

\section{Recommendations}

- CMV retinitis relapse in patients on maintenance therapy can be treated with an induction course of the anti-CMV therapy used for maintenance therapy or another induction therapy (evidence grade IIIA) (10).

- In refractory CMV disease, resistance should be suspected and indirectly confirmed by positive blood tests for CMV replication. Treatment should be reinduced with a different systemic or intraocular therapy, or combination therapy of IV ganciclovir or oral valganciclovir with IV foscarnet (evidence grade IIA) (10). Re-induction options for sight-threatening or refractory CMV disease include switching from valganciclovir or ganciclovir to IV foscarnet, switching to cidofovir, switching to or adding intraocular injections of ganciclovir, foscarnet or fomivirsen (10), or using a ganciclovir intraocular implant and oral valganciclovir (evidence grade IIA) (see Table 5, induction therapy, for recommended dosing). Combination foscarnet/ganciclovir IV therapy is effective in refractory disease but is poorly tolerated (49).

\section{Discontinuation of CMV retinitis maintenance therapy} Because patients starting HAART after a diagnosis of CMV disease often experience immune reconstitution, it is now possible to consider discontinuing maintenance therapy in selected patients $(8,11,50)$.

\section{Recommendations}

- Discontinuation of maintenance therapy can be considered in patients taking HAART who have had a CD4 count greater than 100 cells/ $\mu \mathrm{L}$ for longer than six months (evidence grade IIB) $(8,11,50)$. The decision to discontinue therapy should also take into account the patient's HIV viral load, the anatomical location of retinal lesions, the remaining vision in both eyes, the feasibility of regular ophthalmological follow-up and adherence and adverse events related to both HAART and anti-CMV therapy (evidence grade IIB) (11). The patient, ophthalmologist and primary HIV-treating physician should be consulted when making this decision.

- Patients who discontinue anti-CMV therapy should be monitored closely for changes in immune status or recurrence of CMV disease (evidence grade IIIC). CMV retinitis progression occasionally occurs despite sustained response to HAART (51). Patients should be made aware that recurrence warrants prolonged antiCMV therapy (evidence grade IIB) (51).

- Reinitiation of maintenance therapy should be considered when the CD4 count falls below 100 cells/ $\mu \mathrm{L}$ (evidence grade IIIB) (11).

\section{Nonocular CMV disease}

Nonocular CMV disease is uncommon. There is insufficient evidence to support maintenance therapy after induction with an anti-CMV drug. Nevertheless, many clinicians prescribe maintenance anti-CMV therapy when the disease is serious or recurrent.

GI CMV disease: The most frequent nonocular CMV disease is GI. Oral medication is not recommended because patients may have unreliable drug absorption.

\section{Recommendations}

- Patients with CMV GI disease should receive three weeks of therapy with IV ganciclovir or foscarnet $(10,52)$ (see Table 5, induction therapy, for recommended dosing) (evidence grade IIB).

- Chronic maintenance therapy is not recommended unless patients have a relapse following induction therapy (evidence grade IIIC) (52).

\section{Other nonocular CMV diseases: Other nonocular CMV} diseases are rare, and little data exist to support recommendations. Neurological disease is the second most frequent form of nonocular CMV disease.

\section{Recommendations}

- Patients with neurological CMV infection should receive three to six weeks of IV ganciclovir and/or foscarnet twice daily (evidence grade IIB) $(10,53)$. Patients who respond to induction therapy should be offered IV maintenance therapy (evidence grade IIA).

- Although valganciclovir has not been studied in neurological disease, the pharmacokinetic properties and efficacy of valganciclovir in CMV retinitis suggest that it may be an alternative to ganciclovir for this indication (evidence grade IIIB). 


\section{CONCLUSIONS}

The management of CMV disease in HIV-infected patients has changed due to the introduction of HAART and oral antiCMV therapy. These guidelines are intended to help physicians treat HIV-positive patients with CMV disease based on current knowledge. Physicians expert in the care of HIV-positive patients with CMV disease should, where possible, be involved in treatment decisions for these patients.

ACKNOWLEDGEMENTS: The workshops and the development of the guidelines were supported by an unrestricted grant from Hoffmann-La Roche Canada Inc.

\section{REFERENCES}

1. Sia IG, Patel R. New strategies for prevention and therapy of cytomegalovirus infection and disease in solid-organ transplant recipients. Clin Microbiol Rev 2000;13:83-121.

2. Gallant JE, Moore RD, Richman DD, Keruly J, Chaisson RE. Incidence and natural history of cytomegalovirus disease in patients with advanced human immunodeficiency virus disease treated with zidovudine. The Zidovudine Epidemiology Study Group. J Infect Dis 1992;166:1223-7.

3. Shepp DH, Moses JE, Kaplan MH. Seroepidemiology of cytomegalovirus in patients with advanced HIV disease: Influence on disease expression and survival. J Acquir Immune Defic Syndr Hum Retrovirol 1996;11:460-8.

4. Hoover DR, Peng Y, Saah A, et al. Occurrence of cytomegalovirus retinitis after human immunodeficiency virus immunosuppression. Arch Ophthalmol 1996;114:821-7.

5. Bini EJ, Gorelick SM, Weinshel EH. Outcome of AIDS-associated cytomegalovirus colitis in the era of potent antiretroviral therapy. J Clin Gastroenterol 2000;30:414-9.

6. Jacobson MA, Zegans M, Pavan PR, et al. Cytomegalovirus retinitis after initiation of highly active antiretroviral therapy. Lancet 1997;349:1443-5.

7. Jabs DA, Van Natta ML, Kempen JH, et al. Characteristics of patients with cytomegalovirus retinitis in the era of highly active antiretroviral therapy. Am J Ophthalmol 2002;133:48-61.

8. Jabs DA, Bolton SG, Dunn JP, Palestine AG. Discontinuing anticytomegalovirus therapy in patients with immune reconstitution after combination antiretroviral therapy. Am J Ophthalmol 1998; $126: 817-22$.

9. Mortality in patients with the acquired immunodeficiency syndrome treated with either foscarnet or ganciclovir for cytomegalovirus retinitis. Studies of Ocular Complications of AIDS Research Group, in collaboration with the AIDS Clinical Trials Group. N Engl J Med 1992;326:213-20.

10. Whitley RJ, Jacobson MA, Friedberg DN, et al. Guidelines for the treatment of cytomegalovirus diseases in patients with AIDS in the era of potent antiretroviral therapy: Recommendations of an international panel. International AIDS Society-USA. Arch Intern Med 1998;158:957-69.

11. Masur H, Kaplan JE, Holmes KK; U.S. Public Health Service; Infectious Diseases Society of America. Guidelines for preventing opportunistic infections among HIV-infected persons - 2002 . Recommendations of the U.S. Public Health Service and the Infectious Diseases Society of America. Ann Intern Med 2002;137:435-78.

12. Kempen JH, Jabs DA, Wilson LA, Dunn JP, West SK, Tonascia JA. Risk of vision loss in patients with cytomegalovirus retinitis and the acquired immunodeficiency syndrome. Arch Ophthalmol 2003;121:466-76.

13. Gross PA, Barrett TL, Dellinger EP, et al. Purpose of quality standards for infectious diseases. Infectious Diseases Society of America. Clin Infect Dis 1994;18:421.

14. Verbraak FD, Boom R, Wertheim-van Dillen PM, van den Horn GJ, Kijlstra A, de Smet MD. Influence of highly active antiretroviral therapy on the development of CMV disease in HIV positive patients at high risk for CMV disease. Br J Ophthalmol 1999;83:1186-9.

15. Wei LL, Park SS, Skiest DJ. Prevalence of visual symptoms among patients with newly diagnosed cytomegalovirus retinitis. Retina 2002;22:278-82.
16. Wohl DA, Pedersen S, van der Horst CM. Routine ophthalmologic screening for cytomegalovirus retinitis in patients with AIDS. J Acquir Immune Defic Syndr 2000;23:438-9.

17. Sarrafizadeh R, Weinberg DV, Huang CF. An analysis of lesion size and location in newly diagnosed cytomegalovirus retinitis. Ophthalmology 2002;109:119-25.

18. Robinson MR, Reed G, Csaky KG, Polis MA, Whitcup SM. Immune-recovery uveitis in patients with cytomegalovirus retinitis taking highly active antiretroviral therapy. Am J Ophthalmol 2000;130:49-56.

19. Bachman DM, Bruni LM, DiGioia RA, et al. Visual field testing in the management of cytomegalovirus retinitis. Ophthalmology 1992;99:1393-9.

20. Mutimer HP, Akatsuka Y, Manley T, et al. Association between immune recovery uveitis and a diverse intraocular cytomegalovirusspecific cytotoxic T cell response. J Infect Dis 2002;186:701-5.

21. Karavellas MP, Plummer DJ, Macdonald JC, et al. Incidence of immune recovery vitritis in cytomegalovirus retinitis patients following institution of successful highly active antiretroviral therapy. J Infect Dis 1999;179:697-700.

22. Dunn JP. Immune recovery uveitis. Hopkins HIV Rep 2001;13:9-10.

23. Karavellas MP, Song M, Macdonald JC, Freeman WR. Long-term posterior and anterior segment complications of immune recovery uveitis associated with cytomegalovirus retinitis. Am J Ophthalmol 2000;130:57-64.

24. Goodgame RW. Gastrointestinal cytomegalovirus disease. Ann Intern Med 1993;119:924-35.

25. Goodgame RW, Genta RM, Estrada R, Demmler G, Buffone G. Frequency of positive tests for cytomegalovirus in AIDS patients: Endoscopic lesions compared with normal mucosa. Am J Gastroenterol 1993;88:338-43.

26. Bonacini M, Laine L. Detection of cytomegalovirus in the gastrointestinal tract: Seeking a gold standard. Am J Gastroenterol 1993;88:332-3.

27. Salmon-Ceron D, Mazeron MC, Chaput S, et al. Plasma cytomegalovirus DNA, pp65 antigenaemia and a low CD4 cell count remain risk factors for cytomegalovirus disease in patients receiving highly active antiretroviral therapy. AIDS 2000;14:1041-9.

28. Dodt KK, Jacobsen PH, Hofmann B, et al. Development of cytomegalovirus (CMV) disease may be predicted in HIV-infected patients by CMV polymerase chain reaction and the antigenemia test. AIDS 1997;11:F21-8.

29. Spector SA, Hsia K, Crager M, Pilcher M, Cabral S, Stempien MJ. Cytomegalovirus (CMV) DNA load is an independent predictor of CMV disease and survival in advanced AIDS. J Virol 1999; 73:7027-30

30. Walmsley S, O'Rourke K, Mortimer C, Rachlis A, Fong I, Mazzulli T. Predictive value of cytomegalovirus (CMV) antigenemia and digene hybrid capture DNA assays for CMV disease in human immunodeficiency virus-infected patients. Clin Infect Dis 1998;27:573-81.

31. Verbraak FD, van den Horn GJ, van der Meer JT, et al. Risk of developing CMV retinitis following non-ocular CMV end organ disease in AIDS patients. Br J Ophthalmol 1998;82:748-50.

32. Martin DF, Sierra-Madero J, Walmsley S, et al; Valganciclovir Study Group. A controlled trial of valganciclovir as induction therapy for cytomegalovirus retinitis. N Engl J Med 2002;346:1119-26.

33. Engstrom RE Jr, Holland GN. Local therapy for cytomegalovirus retinopathy. Am J Ophthalmol 1995;120:376-85.

34. Stanley HD, Charlebois E, Harb G, Jacobson MA. Central venous catheter infections in AIDS patients receiving treatment for cytomegalovirus disease. J Acquir Immune Defic Syndr 1994; 7:272-8.

35. Moore DA, Gazzard BG, Nelson MR. Central venous line infections in AIDS. J Infect 1997;34:35-40.

36. Hodge WG, Lalonde RG, Sampalis J, Deschenes J. Once-weekly intraocular injections of ganciclovir for maintenance therapy of cytomegalovirus retinitis: Clinical and ocular outcome. J Infect Dis 1996;174:393-6.

37. Drew WL, Ives D, Lalezari JP, et al. Oral ganciclovir as maintenance treatment for cytomegalovirus retinitis in patients with AIDS. Syntex Cooperative Oral Ganciclovir Study Group. N Engl J Med 1995;333:615-20.

38. Foscarnet-Ganciclovir Cytomegalovirus Retinitis Trial. 4. Visual outcomes. Studies of Ocular Complications of AIDS Research 
Group in collaboration with the AIDS Clinical Trials Group. Ophthalmology 1994;101:1250-61.

39. Parenteral cidofovir for cytomegalovirus retinitis in patients with AIDS: The HPMPC peripheral cytomegalovirus retinitis trial. A randomized, controlled trial. Studies of Ocular Complications of AIDS Research Group in Collaboration with the AIDS Clinical Trials Group. Ann Intern Med 1997;126:264-74.

40. Musch DC, Martin DF, Gordon JF, Davis MD, Kuppermann BD. Treatment of cytomegalovirus retinitis with a sustained-release ganciclovir implant. The Ganciclovir Implant Study Group. N Engl J Med 1997;337:83-90.

41. Diaz-Llopis M, Espana E, Munoz G, et al. High dose intravitreal foscarnet in the treatment of cytomegalovirus retinitis in AIDS. Br J Ophthalmol 1994;78:120-4.

42. Vitravene Study Group. A randomized controlled clinical trial of intravitreous fomivirsen for treatment of newly diagnosed peripheral cytomegalovirus retinitis in patients with AIDS. Am J Ophthalmol 2002;133:467-74.

43. Balfour HH Jr, Fletcher CV, Erice A, et al. Effect of foscarnet on quantities of cytomegalovirus and human immunodeficiency virus in blood of persons with AIDS. Antimicrob Agents Chemother 1996;40:2721-6.

44. Boivin G, Chou S, Quirk MR, Erice A, Jordan MC. Detection of ganciclovir resistance mutations and quantitation of cytomegalovirus (CMV) DNA in leukocytes of patients with fatal disseminated CMV disease. J Infect Dis 1996;173:523-8.

45. Gilbert C, Handfield J, Toma E, Lalonde R, Bergeron MG, Boivin G. Emergence and prevalence of cytomegalovirus UL97 mutations associated with ganciclovir resistance in AIDS patients. AIDS 1998; $12: 125-9$

46. Lalezari J, Lindley J, Walmsley S, et al. A safety study of oral valganciclovir maintenance treatment of cytomegalovirus retinitis. J Acquir Immune Defic Syndr 2002;30:392-400.

47. Martin DF, Kuppermann BD, Wolitz RA, Palestine AG, Li H, Robinson CA. Oral ganciclovir for patients with cytomegalovirus retinitis treated with a ganciclovir implant. Roche Ganciclovir Study Group. N Engl J Med 1999;340:1063-70.

48. Nguyen QD, Kempen JH, Bolton SG, Dunn JP, Jabs DA. Immune recovery uveitis in patients with AIDS and cytomegalovirus retinitis after highly active antiretroviral therapy. Am J Ophthalmol 2000;129:634-9.
49. Combination foscarnet and ganciclovir therapy vs monotherapy for the treatment of relapsed cytomegalovirus retinitis in patients with AIDS. The Cytomegalovirus Retreatment Trial. The Studies of Ocular Complications of AIDS Research Group in Collaboration with the AIDS Clinical Trials Group. Arch Ophthalmol 1996;114:23-33.

50. Torriani FJ, Freeman WR, Macdonald JC, et al. CMV retinitis recurs after stopping treatment in virological and immunological failures of potent antiretroviral therapy. AIDS 2000;14:173-80.

51. Johnson SC, Benson CA, Johnson DW, Weinberg A. Recurrences of cytomegalovirus retinitis in a human immunodeficiency virusinfected patient, despite potent antiretroviral therapy and apparent immune reconstitution. Clin Infect Dis 2001;32:815-9.

52. Blanshard C, Benhamou Y, Dohin E, Lernestedt JO, Gazzard BG, Katlama C. Treatment of AIDS-associated gastrointestinal cytomegalovirus infection with foscarnet and ganciclovir: A randomized comparison. J Infect Dis 1995;172:622-8.

53. Anduze-Faris BM, Fillet AM, Gozlan J, et al. Induction and maintenance therapy of cytomegalovirus central nervous system infection in HIV-infected patients. AIDS 2000;14:517-24.

54. Burke M, Yust I, Katlama C, et al. Cytomegalovirus retinitis in patients with AIDS in Europe. AIDS in Europe Study Group. Eur J Clin Microbiol Infect Dis 1997;16:876-82.

55. Casado JL, Arrizabalaga J, Montes M, et al. Incidence and risk factors for developing cytomegalovirus retinitis in HIV-infected patients receiving protease inhibitor therapy. Spanish CMV-AIDS Study Group. AIDS 1999;13:1497-502.

56. Jacobson MA, Mills J. Serious cytomegalovirus disease in the acquired immunodeficiency syndrome (AIDS). Clinical findings, diagnosis, and treatment. Ann Intern Med 1988;108:585-94.

57. Spector SA, McKinley GF, Lalezari JP, et al. Oral ganciclovir for the prevention of cytomegalovirus disease in persons with AIDS. Roche Cooperative Oral Ganciclovir Study Group. N Engl J Med 1996;334:1491-7.

58. Cochereau-Massin I, Lehoang P, Lautier-Frau, et al. Efficacy and tolerance of intravitreal ganciclovir in cytomegalovirus retinitis in acquired immune deficiency syndrome. Ophthalmology 1991;98:1348-55.

59. Young SH, Morlet N, Heery S, Hollows FC, Coroneo MT. High dose intravitreal ganciclovir in the treatment of cytomegalovirus retinitis. Med J Aust 1992;157:370-3. 


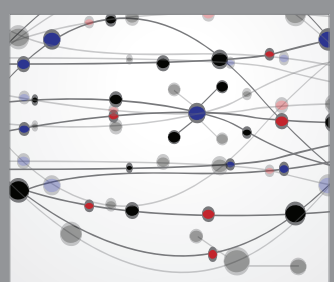

The Scientific World Journal
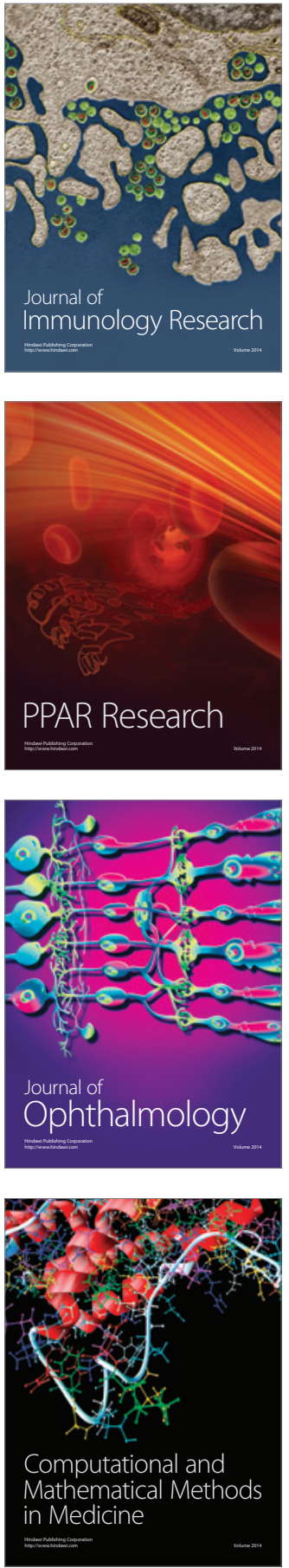

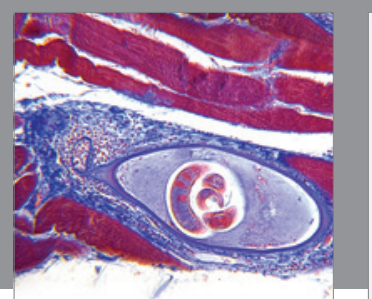

Gastroenterology Research and Practice

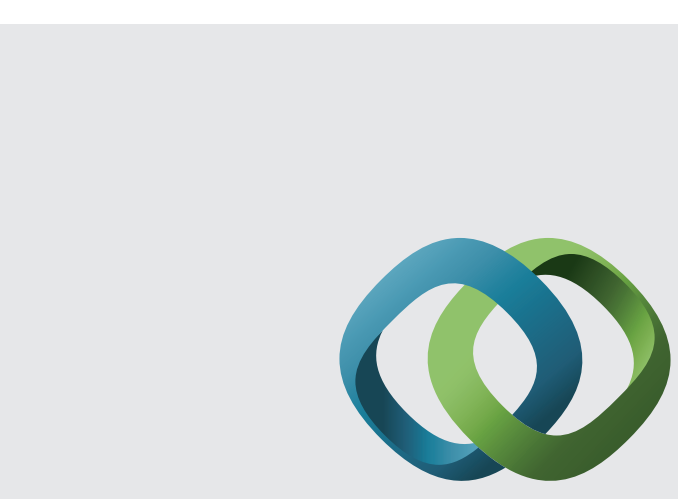

\section{Hindawi}

Submit your manuscripts at

http://www.hindawi.com
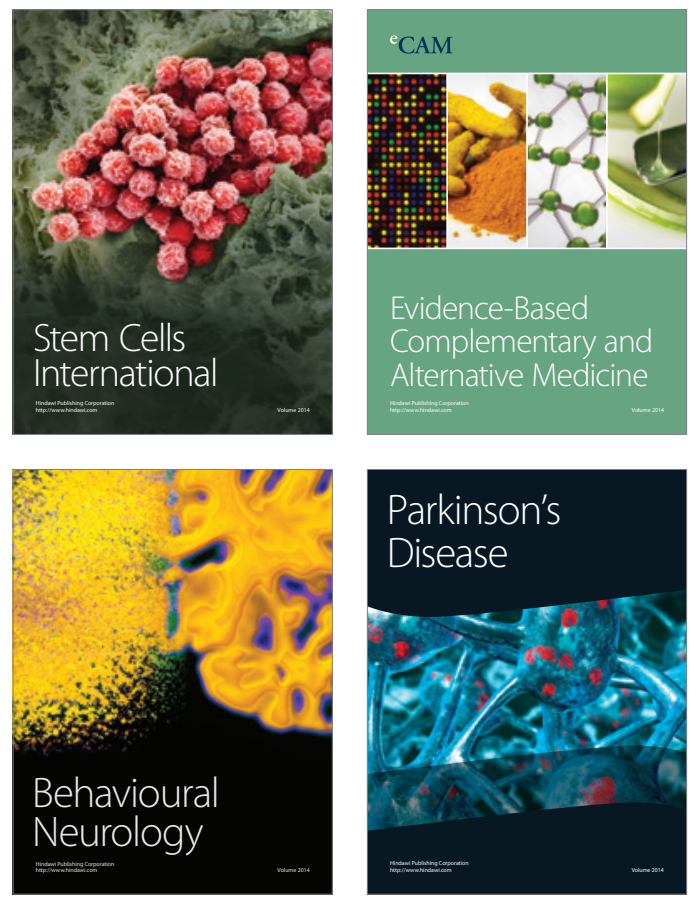
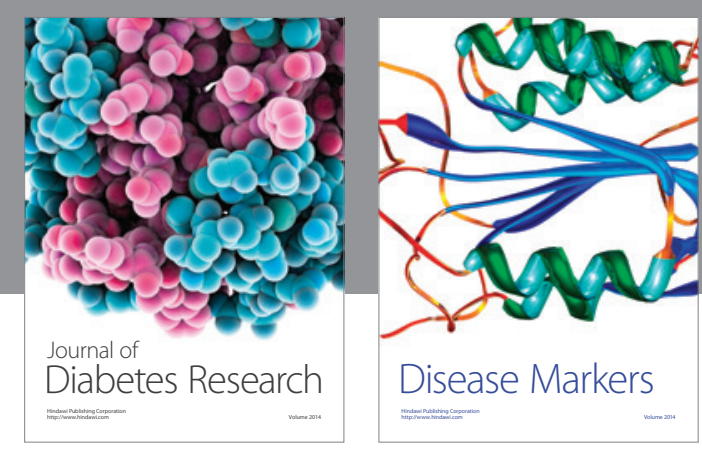

Disease Markers
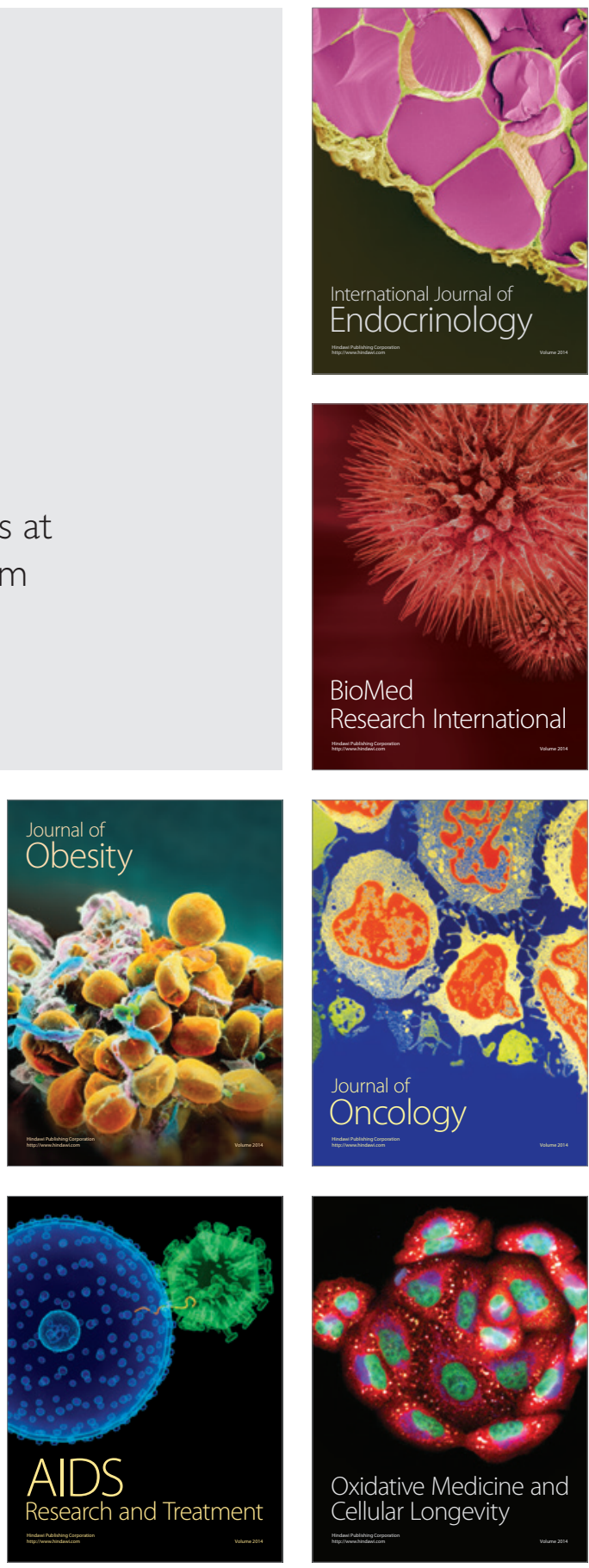